\title{
BIOTRANSFORMATION OF ENDORPHINS BY A SYNAPTOSOMAL PLASMA MEMBRANE PREPARATION OF RAT BRAIN AND BY HUMAN SERUM
}

J.P.H. Burbach, J.G. Loeber, J. Verhoef, E.R. de Kloet, and D. de Wied

Rudolf Magnus Institute for Pharmacology, Medical Faculty, University of Utrecht, Vondellaan 6, Utrecht, The Netherlands

Received January 3, 1979

SUMMARY

$\beta$-Endorphin ( $\beta$-LPH 61-91), $\gamma$-endorphin (61-77), des-tyrosine- $\gamma$-endorphin (62-77), $\alpha$-endorphin (61-76), and $\beta-L P H$ 61-69: either labeled with [125I] at the N-terminal 61-tyrosine residue or unlabeled were incubated with a crude synaptosomal plasma membrane fraction of rat brain or in human serum. At different time intervals the release of $\left[{ }^{125} \mathrm{I}\right]$-tyrosine or the change in immunoreactivity of the endorphins was determined. The cSPM preparation displayed both high aminopeptidase and endopeptidase activities. In contrast, human serum mainly contained aminopeptidase activity. The data suggest that functional endorphin metabolism may occur at the synaptosomal plasma membrane. These membranes may potentially be involved in the formation of behaviorally active endorphin fragments.

$\beta$-Endorphin is present in the brain and in the pituitary gland. In the brain $\beta$-endorphin-1ike immunoreactivity has been detected in cell bodies located in the arcuate nucleus with axons innervating midbrain and 1imbic structures (1). In the pituitary gland the peptide is thought to be produced as part of a large precursor molecule of which it is released enzymatically $(2,3)$. B-Endorphin has long 1 asting analgesic activity and appears to be the most potent endogenous opioid peptide. Shorter $\beta$-endorphin fragments like $\gamma-$ endorphin and $\alpha$-endorphin retain only weak and transient analgesic properties. Essential for such activity is the presence of the N-terminal tyrosine. Removal of this amino acid residue completely eliminates opiate-1ike activity of endorphins $(4,5)$. B-Endorphin and related peptides have been implicated in the control of adaptive behavior. These behavioral effects are independent of opiate receptor sites in the brain, since they are not prevented by opiate antagonists nor dependent on the presence of the N-terminal tyrosine

\footnotetext{
Abbreviations: $\beta-L P H=\beta-1$ ipotropin, cSPM $=$ crude synaptosomal plasma mem-
} brane(s), DT $\gamma E=$ des-tyrosine- $\gamma$-endorphin, $\beta-L P H ~ 62-77$. 
$(4,6)$. DT $\gamma \mathrm{E}$ was found to exhibit neuroleptic like effects in

a number of paradigms $(4,7)$. This led to the hypothesis that

DT $\gamma E$ may have antipsychotic effects. Evidence for this was obtained in a

p1lot study in schizophrenics $(8,9)$. In view of this it was postulated that

an inborn error in the generation of biotransformation of DT $\gamma \mathrm{E}$ might be an

aetiological factor in schizophrenia (10).

The aim of the present study was to investigate whether possible sites

of functional endorphin metabolism e.g. brain synaptosomal plasma membranes

and serum, contain enzyme activities necessary for the formation of des-

tyrosine-endorphins. The release of the $\left[{ }^{125} \mathrm{I}\right]-1$ abeled $\mathrm{N}$-terminal residue

served as a parameter for the determination of aminopeptidase activity. Endo-

peptidase activities were detected by specific radioimmunoassay systems in

which the central and C-terminal region of the endorphins are the immuno-

reactive sites.

MATERIALS AND METHODS

Synthetic human $\beta$-endorphin and related peptides were generously donated by Dr. H.M. Greven (Organon International BV).

Whole forebrains obtained from male Wistar rats (160-180 g) were homogenized in $0.32 \mathrm{M}$ sucrose to give a $10 \%(w / v)$ homogenate. The nuclear-debris fraction was spun down at $\mathbf{1 0 0 0 g}_{\text {av }}$ for $10 \mathrm{~min}$. A crude mitochondrialsynaptosomal fraction was obtained by centrifuging the supernatant at $10,000 \mathrm{gav}_{\mathrm{av}}$ for $20 \mathrm{~min}$. This fraction was lysed by homogenization of the pellet: in distilled water ( $5 \mathrm{ml} / \mathrm{g}$ tissue) and the suspension was kept gently stirred at $0^{\circ} \mathrm{C}$ for $30 \mathrm{~min}$. The supernatant obtained after centrifugation of the suspension at $10,000 \mathrm{~g}_{\mathrm{av}}$ for $20 \mathrm{~min}$ contained the synaptosomal plasma membranes. The membranes were washed and stored at $-20^{\circ} \mathrm{C}$.

Human serum was obtained from healthy subjects.

Iodinated $\beta$-endorphin, $\gamma$-endorphin, $\alpha$-endorphin and $\beta$-LPH 61-69 were prepared by a chloramine-T oxidation method. Five $\mu g$ chloramine-T in $5 \mu 1$ $0.05 \mathrm{M}$ sodium phosphate $\mathrm{pH} 7.4$ was added to a solution of $2.5 \mu \mathrm{g}$ peptide and $0.5 \mathrm{mCi} \mathrm{Na}[125 \mathrm{I}]$ (The Radiochemical Centre, Amersham) in $25 \mu 10.5 \mathrm{M}$ sodium phosphate. After $30 \mathrm{sec}$ the reaction was terminated by addition of $250 \mu \mathrm{g}$ sodium metabisulphite in $100 \mu 10.05 \mathrm{M}$ sodium phosphate followed by $2 \mathrm{mg}$ potassium iodide in $200 \mu \mathrm{l}$ phosphate buffered saline containing $0.25 \%$ bovine serum albumine (Sigma). The labeled peptide was purified by gelfiltration on a $0.5 \times 20 \mathrm{~cm}$ Sephadex G10 column equilibrated in the above described phosphate-saline-albumine buffer.

For determination of $\left[{ }^{125} I\right]$-tyrosine release as a measure for aminopeptidase activity the CSPM fraction ( $0.75 \mathrm{mg}$ protein/ml) was incubated at $37^{\circ} \mathrm{C}$ in $0.9 \% \mathrm{NaCl}$ buffered with $25 \mathrm{mM}$ sodium phosphate in the presence of unlabeled peptide including $\left[{ }^{125} \mathrm{I}\right]$-peptide $\left(6 \times 10^{5} \mathrm{cpm} / \mathrm{ml}\right)$ to a total concentration of $200 \mathrm{nM}$. Incubations were carried out at $\mathrm{pH} 6.8$, the $\mathrm{pH}$ 


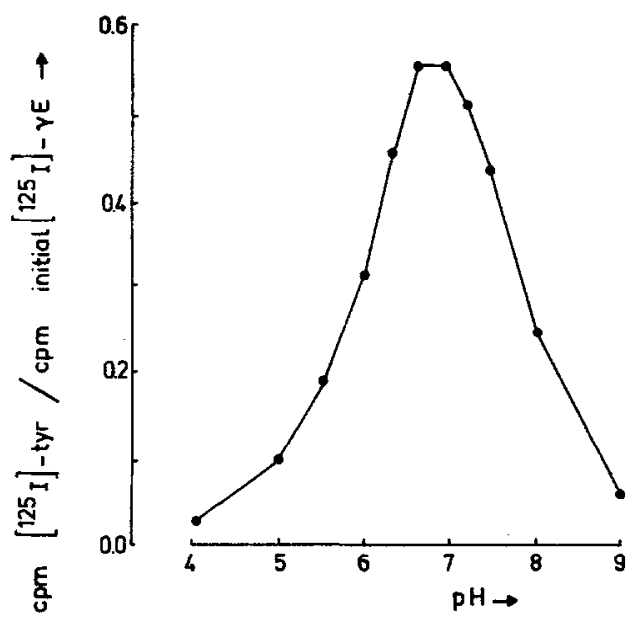

F1gure 1: $\mathrm{pH}$ dependence of cSPM associated aminopeptidase activity measured by the release of $\left[1^{25} \mathrm{I}\right]$-tyrosine from $\left[{ }^{125} \mathrm{I}\right]-\gamma$-endorphin. Incubations were carried out for 10 min at $37^{\circ} \mathrm{C}$ as described in the text.

optimum for the tyrogine releasing aminopeptidase as determined for the release of $\left[{ }^{25} I\right]$-tyrosine from $\left[{ }^{125} I\right]-\gamma$-endorphin at varying pH's (fig. 1 ). Human serum was diluted 10 times with phosphate buffered saline and incubated at pH $7.4 \mathrm{with} 200 \mathrm{nM}$ labeled and unlabeled peptides. At intervals $200 \mu 1$ aliquots of the solution were removed and added to $50 \mu 15 \mathrm{~N}$ acetic acid. When present membranes were removed by centrifugation at $5000_{\mathrm{g}}$ for 5 min. Samples $(100 \mu 1$ ) were applied on $8.6 \times 17.2 \mathrm{~mm}$ Sephadex G10 columns and eluted with phosphate-saline-albumine buffer. At these conditions [125I]tyrosine is retarded on the column.

For determination of immunoreactivity as a measure for endopeptidase activity the cSPM fraction and the human serum were incubated at the above described conditions both at pH 7.4. No labeled peptide was included. At intervals aliquots of the incubation medium were removed, heated at $95^{\circ} \mathrm{C}$ for $10 \mathrm{~min}$ and subjected to radioimmunoassay determination. Procedures and characteristics of the radioimmunoassay systems for $\beta$-endorphin, $\gamma$-endorphin, DTYE, $\alpha$-endorphin and $\beta-L P H$ 61-69 have been described elsewhere (11).

\section{RESULTS}

The release of $\left[{ }^{125} I\right]$-tyrosine from $\left[{ }^{125} I\right]-1$ abeled endorphins is depicted in fig. 2A and 2B. Aminopeptidase activity is present in both cSPM fraction and serum. The incubation time necessary for the release of $50 \%$ of the $\left[{ }^{125} I\right]$-tyrosine $\left(t_{R 50}\right)$ from $\beta-L P H ~ 61-69$ by cSPM associated enzymes appeared to be $2 \mathrm{~min} .\left[{ }^{125} \mathrm{I}\right]$-Tyrosine release from $\gamma$-endorphin and $\alpha$-endorphin was slower and there was no significant difference between the two peptides. For $\beta$-endorphin the apparent $t_{R 50}$ was 55 min. Since a second tyrosine is present at position 87 in the human $\beta$-endorphin sequence, a control experiment 
A

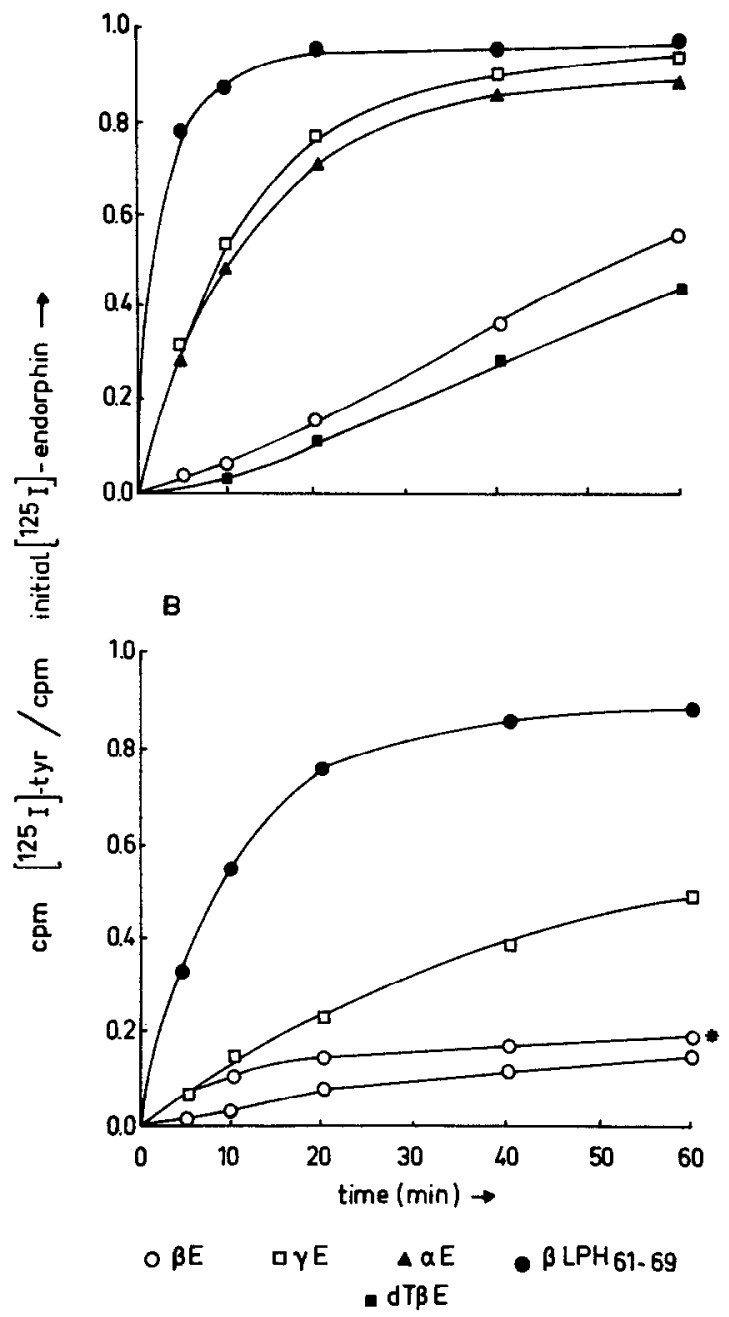

Figure 2: Rate of release of $\left[{ }^{125} I\right]$-tyrosine from $\left[{ }^{125} I\right]$-endorphins by aminopeptidase activities associated with a cSPM fraction of rat brain (A) and in human serum (B). The incubation marked * was carried out in two times diluted serum. For all other experiments serum was diluted ten times. Incubations were performed at $\mathrm{pH} 6.8$ resp. $\mathrm{pH} 7.4,37^{\circ} \mathrm{C}$, as described in the text.

was carried out to investigate whether the release of $\left[{ }^{125} I\right]$-tyrosine from B-endorphin originated solely from the N-terminal tyrosine. Incubation of $\left[{ }^{125} I\right]$-des-tyrosine- $\beta$-endorphin ( $\beta-L P H$ 62-91, DT $\beta E$ ) revealed a considerable liberation of the $87-\left[{ }^{125} I\right]$-tyrosine (fig. 2A). Therefore, the release of the $\mathrm{N}$-terminal tyrosine implied only a minor contribution to the total amount of 
A

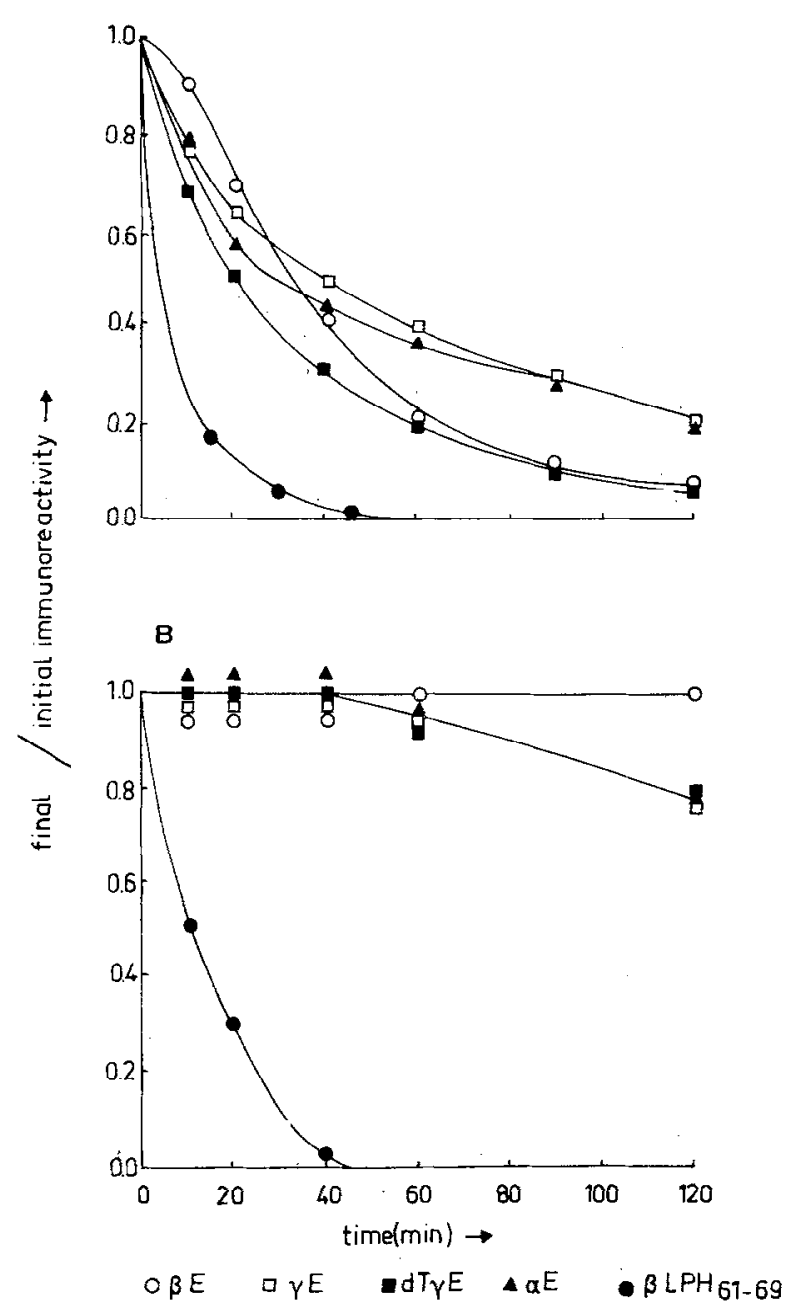

Figure 3: Change of immunoreactivity of endorphins upon incubation with a cSPM fraction from rat brain (A) and with human serum (B) as determined by radioimmunoassay. Incubations were performed at $\mathrm{pH} 7.4,37^{\circ} \mathrm{C}$, as described in the text.

tyrosine released. The actual $t_{R 50}$ for aminopeptidase action was estimated between 240 and 360 min.

In serum a similar fate of the endorphins was observed: a fast tyrosine release from $\beta-L P H ~ 61-69\left(t_{\mathrm{R} 50}=8.5 \mathrm{~min}\right)$, an intermediate one from $\gamma$-endorphin $\left(t_{R 50}=64 \mathrm{~min}\right)$ and a very slow release from $\beta$-endorphin $\left(t_{\mathrm{R} 50}>180 \mathrm{~min}\right)$. A five fold increase in serum concentration only slightly augmented the release of $\left.{ }^{125} I\right]$-tyrosine. 
the peak fractions I to $V$ of the enzymes obtained from rat lung (Fig. 1a) were, respectively, $24,11,18,22$, and $25 \mu \mathrm{mol} / \mathrm{min}$ per mg protein (as assayed with $1 \mathrm{mM}$ 1-chloro-2,4-dinitrobenzene and $1 \mathrm{mM} \mathrm{GSH}$ at $\mathrm{pH} 6.5$ and $30^{\circ} \mathrm{C}$ ). The corresponding specific activities of the liver transferases $B$, C, and A (Fig. 1b) were: 25, 30, and $31 \mu \mathrm{mol} / \mathrm{min}$ per $\mathrm{mg}$ protein.

An attempt was made to identify the transferases obtained from lung with those of Liver by immunological techniques and by comparison of activities versus different substrates. Peaks I and II gave no precipitates with any of the antibodies used, whereas peak III gave a precipitin line with anti-transferase $B$ antibodies. Peaks IV and $V$ both reacted with antibodies raised against transferase $A$ and transferase $C$. We have confirmed with the purified liver transferases the earlier report (3) that forms $A$ and C cross-react immunologically and the distinction between the two forms must accordingly be based on other criteria. The order of elution from the hydroxyapatite column indicated that peak IV of the lung preparation should be the same as form $C$ of $L$ iver and that peak $V$ should be the same as form $A$. This assignment was corroborated by the relative activities obtained with various substrates. As expected for forms $A$ and $C$ (3), both peaks were active with 3,4-dichloro-1-nitrobenzene, but showed an approximately 10-fold lower specific activity than with 1-chloro-2,4-dinitrobenzene. Form A could be distinguished from form $c$ by the use of trans-4-phenyl-3-buten-2-one, because form $C$ is 20-fold more active than form $A$ with this substrate (3). Peak IV gave about 10 -fold higher activity with this substrate than did peak $V$, thus confirming the earlier assignment. The substrate specificity of peak III further supported the identification of this peak with transferase $B$. Peaks I and II, like peak III, were similar to transferase $B$ in giving an activity with 1-chloro-2,4-dinitrobenzene, which was about three orders of magnitude higher than that obtained with 3,4-dichloro-1-nitrobenzene as substrate ( 3 ). 
endorphin, DT $\gamma E$ and $\alpha$-endorphin appear to be equally susceptible to the action of endopeptidases as judged from the change in immunoreactivity. Secondly, B-endorphin is more resistant to aminopeptidase action than the shorter endorphins, a finding which is in agreement with observations of other investigators (12). A consequence of such a mechanism is that des-tyrosine-endorphins may be produced at our experimental conditions. The current methods do not provide direct evidence for the formation of such fragments; although upon incubation of $\beta$-endorphin an increase of $\gamma$-endorphin and $\alpha$-endorphin immunoreactivity was observed (not shown). Moreover, Austen and Smyth have demonstrated the in vitro production of $\gamma$-endorphin, $\alpha$-endorphin and methionine enkephalin during exposure of $\beta$-endorphin to brain membranes (13). $\beta$-Endorphin appears to be resistant to breakdown when exposed to peptidase activities in human serum, as reflected by the preservation of immunoreactivity and the slow release of the N-terminal tyrosine. This is an argument in favour of a mere transport function of serum for $\beta$-endorphin. Shorter peptides are susceptible to serum aminopeptidases proportional to their chain length. B-LPH 61-69 is converted more rapidly than the other endorphins. In addition, the immunoreactivity of this peptide has the shortest half life of the peptides tested. This may be partly due to the characteristics of the antiserum (11). In the $\beta$-LPH 61-69 radioimmunoassay system the corresponding des-tyrosineanalog does not crossreact. Therefore, the release of tyrosine from $B-L P H$ 61-69 will be recognized in this system. Consequently, the loss of immunoreactivity may be caused by a combined action of aminopeptidases and endopeptidases. This reasoning does not apply to the other peptides as the des-tyrosineanalogs crossreact completely in the respective radioimmunoassay systems.

Thus, $\beta$-endorphin has been found to be susceptible to enzymes present in a crude synaptosomal plasma membrane preparation. Accumulation of shorter ß-endorphin fragments like des-tyrosine-endorphins seems therefore likely. The isolation, characterization and quantitation of $\beta$-endorphin metabolites formed by these enzymes are in progress. 


\section{REFERENCES}

1. Bloom, F., Battenberg, E., Rossier, J., Ling, N., and Guillemin, R. (1978) Proc. Nat1. Acad. Sci. USA 75, 1591-1595.

2. Chrétien, M., Crine, P., Lis, M., Gianoulakis, C., Gossard, F., Benjannet, S., and Seidah, N.G. (1978) In: Characteristics and Function of Opioids (van Ree, J.M., and Terenius, L., eds.) pp. 245-257, Elsevier/ North Holland Biomed. Press, Amsterdam.

3. Mains, R.E., and Eipper, B.A. (1978) J. Biol. Chem. 253, 651-655.

4. de Wied, D., Kovács, G.L., Bohus, B., van Ree, J.M., and Greven, H.M. (1978) Eur. J. Pharmaco1. 49, 427-436.

5. Frederickson, R.C.A. (1977) Life Sci. 21, 23-41.

6. de Wied, D., Bohus, B., yan Ree, I.M., and Urban, I. (1978) I. Pharmacol. Exp. Ther, 204, 570-580.

7. de Wied, D., Bohus, B., van Ree, J.M., Kovács, G.L., and Greven, H.M. (1978) The Lancet I, 1046.

8. Verhoeven, W.M.A., van Praag, H.M., Botter, P.A., Sunier, A., van Ree, J.M., and de Wied, D. (1978) The Lancet I, 1046-1047.

9. van Ree, J.M., Verhoeven, W.M.A., van Praag, H.M., and de Wied, D. (1978) In: Characteristics and Function of Opioids (van Ree, J.M., and Terentus, L., eds.) pp. 181-184, Elsevier/North Holland Biomed. Press, Amsterdam.

10. de Wied, D. (1978) In: Characteristics and Function of Opioids (van Ree, J.M., and Terenius, L., eds.) pp. 113-122, Elsevier/North Holland Biomed. Press, Amsterdam.

11. Loeber, J.G., Verhoef, J., Burbach, J.P.H., and Witter, A. (1978) Biochem. Biophys. Res. Comm., submitted.

12. Austen, B.M., and Smyth, D.G. (1977) Biochem. Biophys. Res, Comm. 76, 477-482.

13. Austen, B.M., Smyth, D.G., and Sne11, C.R. (1977) Nature 269, 619-621. 